\title{
EMPIRICAL EVIDENCE OF DEVELOPMENT OF Plastic Clusters
}

\author{
PAVElKOVA, D.; JiRCIKOVA, E.; KNAPKOVA, A.; \\ BIALIC - DAVENDRA, M. \& SAHA, N.
}

Abstract: The development of clusters and cluster policies is one of the sources of attaining competitive advantages of companies and regions. This contribution analyzes a sample of clusters in the plastics industry from different countries of USA, West and Central Europe and Asia, including cluster policies that generate the framework for their growth. Critical factors of cluster performance management based on results obtained from surveys and structured interviews of managers of selected plastics clusters are identified. Although these clusters exist in different parts of the world and operate in different economic and cultural conditions, there are many ideas and opinions shared by their managers introduced in this contribution.

Key words: networking; cluster, cluster initiative, plastics industry
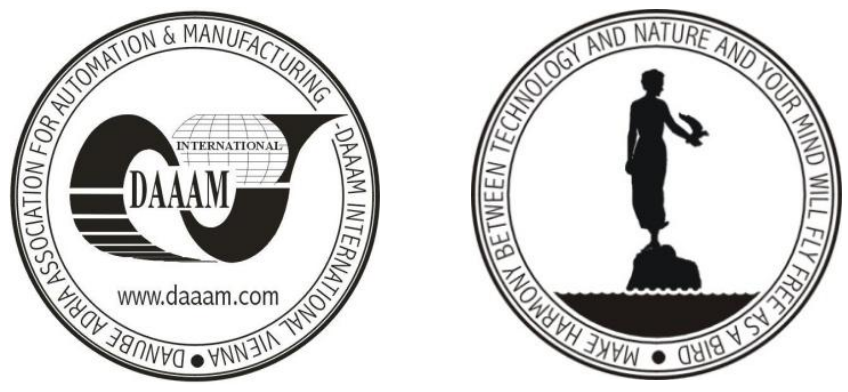

Authors' data: Prof. Dr. Ing. Pavelkova, D[rahomíra $]^{*}$; Ing. Ph.D. Jircikova, E[va]*; Ing. Ph.D. Knapkova, A[driana]*; Mgr. Ph.D. Bialic - Davendra, M[agdalena] ${ }^{* *}$; MBA. Saha, N[ibedita]**, *Centre of Polymer Systems, Tomas Bata University in Zlin, nam. T. G. Masaryka 555, 76005 Zlín, Czech Republic, **Faculty of Management and Economics, Tomas Bata University in Zlín, nam. T. G. Masaryka 5555, 76005 Zlín, Czech Republic, pavelkova@fame.utb.cz, jircikova@ fame.utb.cz, knapkova@fame.utb.cz, bialic@fame.utb.cz,nibedita@fame.utb.cz

This Publication has to be referred as: Pavelkova, $\mathrm{D}$ [rahomira]; Jircikova, $\mathrm{E}$ [va]; Knapkova, A[driana]; Bialic - Davendra, M[agdalena] \& Saha, N[ibedita] (2011). Empirical Evidence of Development of Plastic Clusters, Chapter 50 in DAAAM International Scientific Book 2011, pp. 619-634, B. Katalinic (Ed.), Published by DAAAM International, ISBN 978-3-901509-84-1, ISSN 1726-9687, Vienna, Austria DOI: $10.2507 /$ daaam.scibook.2011.50 
Pavelkova, D.; Jircikova, E.; Knapkova, A.; Bialic-Davendra, M. \& Saha, N.: Emp...

\section{Introduction}

Being competitive in today's globalized market poses a challenge for entrepreneurships. Individual entities start to see the opportunity for further development in networks of cooperation. Clusters as a structure appears as a good combination of collaboration and competition, where participating entities have the possibility to join their efforts and resources in order to achieve competitive advantage above others. Clusters are becoming a modern way of cooperation of both profit and non-profit organizations. Successful clusters enhance the efficiency of individual companies and drive the economic development in many countries.

The literature lays out various definitions of the cluster concept, including the terms industrial cluster, regional cluster or innovation cluster. Porter (1990) defines clusters as "geographic concentrations of interconnected companies, specialized suppliers, service providers, firms in related industries and associated institutions, such as universities, agencies and associations of different orientations, which compete, but also cooperate."

It is also very common that the formation of clusters and support of its development is connected with the so-called cluster initiative. The cluster initiative, according to the Cluster Initiative Greenbook (2003) is defined as "an organized effort focused on the increase of growth and competitiveness of a cluster in the region with the participation of cluster companies, government and/or research community". Since the 1990s, a large number of cluster organizations have been formed as publicprivate partnerships with the purpose of promoting the growth and competitiveness of clusters (Sölvell et al., 2003; Ketels et al., 2006).

After the cluster concept was introduced and popularized by Michael Porter, the cluster-based policies started to develop in various countries, however, with different intensity, showing variety of initiatives and approaches. According to the Expert Group ${ }^{1}$ (European Commission, 2005), "cluster policy is developed by national governments in cooperation with regional and local governments". Since clusters link within their networks numerous entities from industry (business), education and science as well as governmental spheres, therefore, cluster policy embraces all policies affecting clusters' functioning. As the European Commission aptly underlines "a cluster policy is not an isolated, independent and well-defined discipline. It embraces all policies that affect the development of clusters, taking into account the synergies and interchanges between these policies". Cluster based-policy through its set of activities i.e. strategies, programs, procedures, can be implemented on different levels such as national, regional and/or local level. Also, different spectrum of cluster policies can be observed, as cluster policy can be, for example, closely linked to regional policy, industrial policy, innovation policy, science and technology policy etc., and due to the range of applied policy e.g. policy which

\footnotetext{
${ }^{1}$ European Commission (2005). Final report of the Expert Group on Enterprise Clusters and Networks. European Commission, Belgium.
} 
generally affects business conditions or which is strictly focused on clusters (clusterspecific) (Pilarska, 2010). As Kačírková (2008) depicts, cluster-based policy can be implemented through defined programs explicitly oriented on clusters, can be implemented within the strategy oriented on stimulation of competitiveness in general, or within the strategies of general economic development.

Now then, cluster consolidates the world of industry, science and education giving the opportunity to exchange knowledge, combine financial and human capital, assets, technologies and ideas into the development of one "organism". It is characterized by a geographic concentration of companies in relatively closely related fields (branch specialization), which cooperate and share mutual needs (are complementary to one another). Each cluster is different and poses its own strategy of activity, management and financing. Nevertheless, the questions arise: are there any conditions that the cluster has to fulfil in order to become successful? Is there any "key" for success? While searching for these answers, it is important to take a good look both at the background and cluster-based policy of the country in which the cluster operates, and the experience of clusters, which are already considered as successful.

\section{Methodology of research}

A research team at Tomas Bata University in Zlín, Faculty of Management and Economics along with its partners carried out a survey using questionnaires and interviews with cluster managers in period of 2007-2010. The results of this survey show the approach of cluster initiatives to management and financing of clusters, activities which clusters offer to their members and answer the question of critical factors for the successful development and high performance of clusters.

Cluster policy of the selected countries was investigated by study of available documents and by the questionnaire survey of state and regional agencies supporting cluster development.

Following text analyzes a sample of seven clusters in the plastics industry from different regions and countries (Western Europe - Norway, Austria; Central Europe Czech Republic, Slovak Republic, Poland; Asia - India; North America - USA), including cluster policies that generate the framework for their existence and growth.

Plastic clusters were selected from different regions and with different stages of life cycles.

Results of research are presented in following structure:

- brief description of cluster policy in the selected countries

- plastic clusters in selected countries - their foundation, structure and common activities

- summarization and comparison of the opinions of managers of the selected plastic clusters regarding the factors that were found to be of cardinal importance for a successful cluster development based on different studies. 
Pavelkova, D.; Jircikova, E.; Knapkova, A.; Bialic-Davendra, M. \& Saha, N.: Emp...

\section{Clusters and Cluster Policy in the Selected Countries}

In the Czech Republic, the first activities directed towards clusters support started to develop in 2003. In July 2005, the National Cluster Strategy for the years 2005-2008 was elaborated as a main document in the clusters area. It contained the main principles, measures and aims of application of a successful economic model of a cluster in regards to the conditions existing in the Czech Republic.

The most important component of financing clusters from public sources in the Czech Republic provides structural funds of EU. Within these funds in the time frame 2004-2006 the Operational Program Industry and Enterprise (OPIE), program Clusters (Klastry) was realized. The program priorities were divided into two phases:

- seeking out and identifying enterprises open for cooperation and preparation for potential cluster creation,

- cluster establishment and further development - financing business and activities of cluster initiative throughout three years period.

At present, Programme OPIE Clusters is followed by the Operational Programme Enterprise and Innovation 2007-2013 - OPEI COOPERATION with its focus on supporting formation and development of cooperation groups - clusters and technological platforms. The current aim of the program is to create a favourable entrepreneurial environment, improve conditions for enterprising and innovation, and develop a competitive advantage, thanks to the improvement of linkages among research, education and entrepreneurial spheres. Within supported activities, common cluster projects in the area of technical infrastructure with innovative character, in the area of innovation, cluster promotion, human resources and networking, sharing know-how and capacity can be highlighted. The new program (against the previous one) was broadened. It is for example less restricted in regards to the industry sphere. So called "cluster mapping" is not implemented and a cluster formalization is not primarily limited to company membership from a certain region and/or maximum of two adjacent regions. Nevertheless, other regulations such as the fact that a cluster has to have minimum of 15 independent members, at least $60 \%$ of cluster members have to be Small and Medium Enterprises (SMEs) and a tertiary education institution (university) or research institute has to participate in a cluster, were maintained.

Clusters are an object of support within documents devoted to realizing the European Union (EU) coherent policy - within EU structural funds for the years 2007-2013. The policy towards clusters and cluster initiatives is being realized not only on the national but also on regional government level (within Regional Operational Programs - Regionální operační programy, and regional innovation strategies).

In Slovak Republic, the cluster concept appeared recently within the governmental documents such as: Innovation strategy of the Slovak Republic for 2007-2013 and Operation Programme Competitiveness and Economic Growth as part of National Strategic Reference Framework 2007-2013. The latter is the first policy document mentioning clusters and their role, and directed to the concept of clusters as a tool for companies competitiveness' development. 
The main institution responsible for implementing cluster policy is the Ministry of Economy of the Slovak Republic. However, there are other institutions such as National Agency for Development of SMEs, Slovak Agency for Trade and Investments and Slovak Energy and Innovation Agency who play supportive role in implementing cluster policy.

Only recently, in August 2010, the Union of Slovak Clusters ("Únia Klastrov Slovenska - ÚKS") was established by six Slovak clusters. Its main goal is to stimulate the development of employment and quality of education, to increase cooperation and communication among domestic and foreign companies and to support the regional development as well as the competitiveness of institutions and companies in Slovakia.

In Poland, the cluster-based policy was introduced in 2002. Further attention to this concept commenced in 2004, when an effort to identify and map out potential clusters was undertaken for the first time. In 2005, Training Program on Clustering and in 2007 the Pilot Project: Support for Clusters, both based on EU structural funds were provided by the Polish Agency for Entrepreneurial Development PAED government agency subordinated to the Ministry of Economy, in order to promote cluster development and expand national and international cooperation.

On the regional level, the most important instrument of support was the Zintegrowany Program Operacyjny Rozwoju Regionalnego ZPORR 2004-2006 (the Integrated Regional Operational Programme) with the aim to increase a regional innovativeness through development of cooperation (transfer of knowledge and innovation) among $R \& D$ and private sectors.

Furthermore, within the time frame of 2006-2009, other initiatives realized in the EU policy level appeared including INNET. Within INNET, the Innovation Express (IE) - joint call for proposals supported by national/regional agencies and authorities was introduced in 2008. Its main goal was to support activities, which "initiate, develop and enhance technological co-operation between European clusters for the prime benefit of their SME members" (www.proinno-europe.eu). Within IE, a special "matching tool" was developed with an objective to give clusters an opportunity to find potential partners for future trans-national cooperation.

In connection with gradually accrued interest in networking and cooperation, new national strategies and programs had to include clusters' concept within their priorities. Therefore, the ongoing Operational Program Innovative Economy OP IE (Program Operacyjny Innowacyjna Gospodarka - PO IG) for the years 2007-2013 contains a specified priority "Diffusion of Innovation" oriented on development of co-operational connections (networking) and common investments of groups of entrepreneurs. A Cluster coordinator is the one who can apply for financial support within the OP IE program; however, it has to meet specified conditions e.g. in regards to its legal character, nature of activity, headquarters, have to possess experience in managing the cluster/cluster initiative etc. The cluster as a structure, according to PAED, is a group of independent entrepreneurs (where the minimum half of them have to be SMEs) operating in a particular sector, including start-up companies, engaged in innovative activities, research organizations and business institutions. 
Financial support for clusters also appeared with the Pilot program for the years 2008-2010 Bonds for innovation (Bon na innowacje) whose main idea was to initiate contacts among micro and small enterprises and research institutions (www.parp.gov.pl).

In Austria, clusters have been supported from the early 1990s. Each cluster can count on public support in terms of cluster management and cluster funding. Cluster development in Austria operates at different levels: regional clusters, nationwide clusters, and industry-research linking competence centres. Regions are entitled to set their own innovation and technology policies. They take over the active part of building clusters, i.e., cluster management and co-operation platforms. However, national institutions provide a general framework for regional cluster policy: financial support, technology transfer programs, training plans, and $R \& D$ policies.

Since 1998, the Regional Government of Upper Austria has pursued a clusteroriented economic and technology policy on the basis of the "Upper Austria 2000+" Strategic Program. The aim is to achieve a sustained improvement in the competitiveness of the location. TMG, the regional institution for the promotion of technology and marketing (owned by the Regional Government of Upper Austria) was given responsibility for cluster management. For period 2005-2010, new Strategic Program "Innovative Upper Austria 2010" was prepared. The focal point of the program is formed by a concentration of capacity on five main areas comprised by: R\&D, networks, EU-networking, Upper Austria as an economic and technology location, and professional qualification. Upper Austria is the European leader with regard to economic networking. No other region has such a well-established climate of cooperation.

In Norway, there has been an increasing interest in innovation systems theory and the concept of clusters in among development agencies and the ministries, especially in the Ministry of Trade and Industry and the Ministry of Local Government and Regional Development. This has led to the establishment of several instruments that are to encourage networking and the distribution of knowledge, competence and personnel in various parts of the innovation system. This applies to programmes like Mobilisation for R\&D related innovation, Value Creation 2010, ARENA and Norwegian centres of expertise.

Arena is a national program for long term development of regional business clusters. The program offers both advisory and financial support. The objective is to strengthen the clusters innovative ability through a stronger and more dynamic interaction between the industry, $\mathrm{R} \& \mathrm{D}$ institutions, universities and the public sector. The interaction is to be long-term, goal-oriented and focused on innovative collaboration, international awareness, access to knowledge and new business. Arena is a national program owned by Innovation Norway, SIVA and the Research Council of Norway. As of October 2008, there were 22 regional clusters (projects) within the program.

The Norwegian Centers of Expertise (NCE) Program is jointly owned and implemented by the three main Norwegian innovation agencies: Innovation Norway, the Research Council of Norway and SIVA. Norway has appointed twelve strong 
clusters consisting of world class enterprises in their field. The NCE-clusters must be further developed to motors for industry development. They must speed up creation in regional business environments, through cooperation between companies, researchers, colleagues and public authorities. In addition, they must be internationally oriented. The NCE programme has a long-term perspective. The companies which are participating are offered professional and financial support for development processes for up to ten years.

Clusters in the USA vary from state to state and virtually every state in the union has one or more clusters. They generally fall under the purview of a state's economic development office and often seek to transfer technology developed at one or more of the state's universities to entrepreneurs who supply capital, marketing, and management to turn the technology into a successful business. Other clusters types are usually focused on developing and diversifying types of businesses that already have a presence in the state, such as developing downstream industries in wood products in states that already have a lumber industry. The growing interest in clusters represents an important change from traditional economic development which has tended to choose individual companies as the vehicle for state economic development, rather than groups of companies.

In India, SMEs sector has acquired a prominent role in the socio-economic development of the country during the past 50 years. Thus, apprehending the value and importance of small enterprises in the development and growth of the economy, Govt. of India (GOI) constituted an Expert Committee on Small Enterprises in 1996 headed by Prof Abid Hussein. This Expert Committee advocated industrial cluster development and support policies, strategies as the pivot of the small enterprises development. Previously in 1989, State Bank of India had initiated a technology upgradation program targeted at select clusters. Beside, in 1992 Small Industries Development Bank of India had initiated technology focused cluster development program. On the other hand, in 1997 UNIDO initiated its Cluster Development Program. In 1998 Small Industries Development Organization (SIDO), an arm of the Govt. of India started its program on industrial cluster development. India has largely two types of clusters, Industrial (SME) Clusters and Artisanal Clusters. There are around 400 SME clusters and 3500 Artisan Clusters in India. In India cluster alone contribute up to $40 \%$ of the country's industrial output comes from cluster. And 60 $\%$ of the country's manufactured exports come from cluster. Beside they also have a significant workforce and a high share in employment generation.

In India, the most significant constituent of financing the clusters done through enhancing the project cost for Common Facility Centre (CFC), Soft Interventions (SI) and Infrastructure Development (ID). It is observed that from Rs. \$ 0.2 million to Rs. $\$ 125$ million has been invested for cluster development in India. On the other hand, a billion dollar could be invested in 2007-12 .

In 2002, Govt. of India took the initiative to start up a chapter of an international networking group for entrepreneurs called TiE (The World's Largest

\footnotetext{
${ }^{2}$ http://www.clusters.org/faq.asp, www.commerce.nic.in
} 
Network of Entrepreneurs $)^{3}$ to expand their networks in India and abroad in order to promote sustainable economic growth policy and contributing to the achievement of the Millennium Development Goals in developing Asia. In 2003 the Ministry of Micro and Small Enterprises (MSME) initiated a scheme Small Industry Clusters Development Programme (SICDP). Earlier it was called Integrated Technology Upgradation and Management Programme (UPTECH) where the interventions in industrial clusters were first initiated in 1998. The Micro and Small Enterprises, scheme was renamed as Micro and Small Enterprises - Cluster Development Programme (MSE-CDP) and the Integrated Infrastructural Development (IID) Scheme of the Ministry was subsumed under MSE-CDP with its existing funding pattern, in October 2007. ${ }^{4}$ It is to be noted though India's cluster development policy shows high progress, but there lies also some difficulties. Such as since 2008 and continued till 2010 the Indian Micro, Small and Medium Enterprises maintain growth and perform steadily. But due to fierce of high competition it is speculated that though it is growing very fast, but this growth may not be sustained in 2011-12. As owing to several problems in policy that create hindrance for the rapid progress in some cluster development policy issues. Such as inadequate financial support; inability to promote their products and services in domestic and international markets; lack of support from government organizations, large enterprises, etc; lack of appropriate need-based training and development programmes; lack of knowledge about low-cost brand communication solutions; unavailability of latest news, trends and technologies and lack of adequate networking opportunities and poor knowledge management ${ }^{5}$.

\section{Examples of Plastic Clusters and Their Strategies, Goals and Preferred Activities}

Plastic cluster (Czech Republic) ${ }^{6}$ was officially founded in the beginning of 2006 comprising of 18 representatives of the founders firms. The Plastic cluster is an open membership of legal entities processing plastics in Zlín region. The cluster has 25 members today and about $80 \%$ of them are SMEs. The cluster links companies in the areas of: plastics processing (90\%), mould and tooling construction (5\%), raw materials \& recycling traders $(5 \%)$. The cluster also cooperates with the university. The cluster members employ more than 3,500 people (50\% share of employment in plastic industry in the region) and have total annual sales of $€ 200$ million. The average export quota is around $44.5 \%$.

Four main spheres of cooperation were set by the firms interested in establishing the cluster:

- Human resources - The goal is to set up a special training centre providing qualified labour force

- Shared purchase - shared purchasing of electricity and material

\footnotetext{
${ }^{3}$ http://www.tie.org

${ }^{4}$ Daily News, The India Post. (2010). Cluster Development Programme (MSE-CDP), 24th May.

${ }^{5}$ SME TIMES (2010). MSMEs in 2011- Sustained growth a far cry, 31st Dec.

${ }^{6}$ More about this cluster can be found at http://www.plastr.cz
} 
- Research and Development - The goal is to build a laboratory for material, tools, and technology testing

- Presentation of the cluster - creation of the cluster's logo, design manual, web page, catalogue of products etc.

Slovak Plastic Cluster (Slovak Republic) ${ }^{7}$ was established in 2009 as an association of legal entities in the area of plastic production and processing. Cluster creates 32 enterprises in plastics industry, where $84 \%$ constitutes SMEs (within which $74 \%$ are medium-size companies). Companies within the cluster cover most of the value chain, where processors (manufacturers), equipment manufacturers, commercial organizations, scrap processors, service organizations, research institutes, university and other educational institutions are present. Cluster cooperates as well with other non-member enterprises within the whole value chain. The main goal of the cluster is to develop in the field of plastics:

- networking,

- education (on the level of high school, university and lifelong learning),

- research and development,

- and technology transfer.

The Tarnów Industrial Cluster (Poland) ${ }^{8}$ was established in 1999 as a jointstock company originally under the name The Tarnów Industrial Cluster 'Plastic Valley'. Among 34 shareholders were inter alia Tarnów community centre, communities of the former Tarnów voivodeship, Zakłady Azotowe w TarnowieMościcach S.A., Zakłady Mechaniczne 'Tarnów' S.A., Chamber of Commerce in Tarnów, Chamber of Crafts, private SMEs from the plastics processing industry and individuals. In 2008, the name 'Plastic Valley' was withdrawn in order to open the possibility of joining the cluster by companies from other branches such as: electronics, wood and metal etc. Nevertheless, plastics maintained as the leading branch. Currently, there are 28 enterprises (processors-manufacturers) in the cluster, where $93 \%$ constitute SMEs. The Tarnów Industrial Cluster is also cooperating with other companies (not cluster members) which are raw material (energy) suppliers. The main goals of the cluster are as follows:

- Creating conditions for comprehensive economic development of the region and job vacancies, especially through implementation and realization of the project of Regional Industrial Park in Tarnów.

- Creating an attractive, compatible with EU standards area purposed for leading an economic activity and investing, set apart by good localization, new infrastructure, low costs of usage a productive property and professional auxiliary services.

- Supporting SMEs within the region by offering technical and legal consultancy, by looking for partners suitable for cooperation and delivering information about firms to their potential partners.

\footnotetext{
${ }^{7}$ More about this cluster can be found at http:// www.spksk.query.sk

${ }^{8}$ More about this cluster can be found at http:// www.tkp.com.pl
} 
The Plastics-Cluster (Kunststoff Cluster $=\mathrm{KC}$, Austria) ${ }^{9}$ is a superordinated, plastics sector network. It was founded in 1999. The legal body of the cluster is Clusterland Upper Austria, Ltd. (Linz, Upper Austria) and Ecoplus (The Business Agency of Lower Austria Ltd.) The KC is the largest plastics branch network for plastics technology. The network consists of 409 partner companies. The KC links companies in the areas of: plastics processing, plastics machinery, mould and tooling manufacture trading, raw/recycled material production, technical services to the plastics industry and institutes and R\&D transfer centres. The KC partners employ more than 54,000 people and have total annual sales of $€ 12$ billion. The average export quota is around $65 \%$ and R\&D quota $3.6 \%$. About $85 \%$ of the KC partners are SMEs. The regional division of the KC partners is Upper Austria $47 \%$, Lower Austria $19 \%$, Vienna $9 \%$, other federal states $15 \%$, from abroad $10 \%$.

The main goals of the cluster are as follows:

- To support, initiate and coordinate inter-company teamwork, as well as cooperation between companies and technology transfer bodies in the plastics sector. One of the most important aspects of cluster activities is constituted by cooperation projects among the partners. Joint projects are divided into three thematic categories: Technology projects - $65 \%$ (e.g. technology and product development), Organizational projects - $24 \%$ (e.g. reengineering, benchmarking in injection molding and tool engineering), Training projects $11 \%$ (e.g. training co-operation, Kaizen co-operation).

- To concentrate potential and competencies in order to increase the innovative capacity and international competitiveness of the partners.

Borg Plast-Net Cluster (Norway) was established in 2000 in Fredrikstad as a membership of legal entities. There are 36 companies in the cluster, which are making the core of the cluster. About $92 \%$ of the cluster partners are SMEs. Firms are representing different branches, but most of the companies in the cluster are representing the plastic industry. They are plastic processors and producers, raw material suppliers, scrap processors and equipment manufacturers. Borg Plast-Net is also cooperating with other companies which are not part of the cluster, like raw material suppliers, equipment manufacturers, commercial organizations and service organizations. The cluster is also cooperating with 6 institutions including university and regional representatives. The clusters members employ around 900 people and have total annual sales of $€ 190$ million. The average export quota is around $50 \%$.

At the beginning of the Borg Plast-Net there were three main goals of the cluster. They are as follows:

- Sharing of information, know-how, technologies, capacity - The main goal is to build good relationships and mutual trust among the cluster members

- Joint marketing strategy - The main goal is to build up through joint marketing the good reputation of the cluster

\footnotetext{
${ }^{9}$ More about this cluster can be found at http:// www.kunststoff-cluster.at
} 
- Enhance competitiveness and develop new technologies

Wisconsin Plastic Cluster Partnership (USA) was established in 1998 as a nonprofit organization. The cluster has 29 members and about $90 \%$ of them are SMEs. The cluster links companies in the areas of: plastics processing, commercial organizations, research institutes, technical colleges and university. The cluster also cooperates with raw material suppliers and service organizations. The cluster partners employ more than 3,500 people and have total annual sales of $\$ 300$ million U.S dollars. The average export quota is around $15 \%$ and $\mathrm{R} \& \mathrm{D}$ quota $4 \%$. The primary objective of the cluster is to develop educational and training programs to support the plastic industry. The vision of the cluster is: "Wisconsin, the center for plastics in the U.S." The cluster has these goals:

- Research and Development (applied and pure)

- Education Program

- Achieve regulation friendly

- Be a Green Industry

- Obtain fair share of federal funding

Aluva Plastic Cluster (India) ${ }^{10}$ Aluva Plastic Consortium Pvt. Ltd was formed in the year 2004 under the Small Industry cluster development programme of the Government of India and Government of Kerala. Plastic cluster is an open membership cluster legally formed by Private Limited Company with the presence of 108 numbers Cluster (beneficiaries) and 28 numbers of other consortium member. It is the collective endeavor of the cluster members, which gives the necessary impetus to the growth of the consortium. Co-operation among the members and their dedication to the noble ideal makes the financial, technical and marketing facets of the consortium less intricate. The historical background shows that about 30 to 40 years ago Micro/Small scale plastic industrial units has been functioning in Aluva, Ernakulam District. The capital investment of these industries vary from Rs. 5 to 350 Lakhs. Private banks are associated with this cluster for financing. The State is presently in the process of implementing more than ten projects with the technical and financial support both from the Central and State Government. Thus Government of Kerala initiated the Cluster Development Programme (CDP) on the UNIDO guidelines from the year 2003.

The main spheres of co-operation were set by the firms interested in establishing the cluster:

- Market Expansion to set up product marketing and brand building for making mould and there by they can produce fresh items in their units and this will help to increase their market potential.

- Planning to set up a Common Facility Centre for Mould making, mould repairing, machinery spare parts manufacturing, injection moulding etc.

\footnotetext{
${ }^{10}$ More about this cluster can be found at http://aluvaplastics.com
} 
which will benefit the units. CFC can be utilized by the members in order to cater bulk orders.

- Improving the performance of the Plastic Cluster as a whole by improving the quality of the products, product differentiation.

- Human resources to solve the problems of knowledge fragmentation and co-ordination. To set up special training centre and training programme for the Government officials, bankers, financial institutions, and also for the cluster members.

- Cost Reduction to have an Interactive sessions and meetings between potential cluster actors/Cluster Development Executives (CDE's) of the State with Stakeholders of developed clusters from various parts of the Country. Establish Raw Material Bank and Common Facility Centre. With the help of State Government this cluster took the initiative for financial assistance and Technology Development Fund scheme.

- Research and Development to create an independent subject that will provide $R \& D$ in the future. To build a network with the research institutions and the industries.

- Cluster firms' presentation - Cluster firms arrange a regular meeting with the other cluster members and joint participation on Marketing linkages, outlets, and participation in fairs abroad and on brand creation.

The main vision of plastic cluster was to become a full-fledged cluster in India with self developed infrastructure by 2008 .

In the following table (Table 1) activities offered to members of the plastic clusters from the different countries (mentioned above) supporting networking, human resource development, research, common business cooperation, support activities etc. are summarized.

\begin{tabular}{|l|c|c|c|c|c|c|c|}
\hline & CZ & SK & PL & AU & NO & USA & IND \\
\hline In the area of networking: & & & & & & & \\
\hline Information support (joint web page,...) & $\checkmark$ & $\checkmark$ & $\checkmark$ & $\checkmark$ & $\checkmark$ & $\Rightarrow$ & $\checkmark$ \\
\hline Common workshops, meetings... & $\checkmark$ & $\checkmark$ & $?$ & $\checkmark$ & $\checkmark$ & $\checkmark$ & $\checkmark$ \\
\hline Arranging contacts among cluster members & $\checkmark$ & $\checkmark$ & $\checkmark$ & $\checkmark$ & $\checkmark$ & $\checkmark$ & $\checkmark$ \\
\hline $\begin{array}{l}\text { Arranging contacts with vendors or } \\
\text { customers }\end{array}$ & $\checkmark$ & $\checkmark$ & $\checkmark$ & $\checkmark$ & $\Rightarrow$ & $\checkmark$ & $\checkmark$ \\
\hline In the area of human resources: & & & & & & & \\
\hline $\begin{array}{l}\text { Organization of joint seminars and } \\
\text { conferences }\end{array}$ & $\Rightarrow$ & $\checkmark$ & $\checkmark$ & $\checkmark$ & $\checkmark$ & $\checkmark$ & $\checkmark$ \\
\hline Training of employees & $\Rightarrow$ & $\checkmark$ & $?$ & $\checkmark$ & $\checkmark$ & $\checkmark$ & $\checkmark$ \\
\hline Cooperation with educational institutions & $\checkmark$ & $\checkmark$ & $?$ & $\checkmark$ & $\checkmark$ & $\checkmark$ & $\checkmark$ \\
\hline In the area of research and innovation: & & & & & & & \\
\hline Joint research and development & $\Rightarrow$ & $\checkmark$ & $?$ & $\checkmark$ & $\checkmark$ & x & $\checkmark$ \\
\hline
\end{tabular}




\begin{tabular}{|l|c|c|c|c|c|c|c|}
\hline Cooperation with research institutions & $\Rightarrow$ & $\checkmark$ & $\Rightarrow$ & $\checkmark$ & $\checkmark$ & $\checkmark$ & $\checkmark$ \\
\hline Innovations of products and processes & $\Rightarrow$ & $\checkmark$ & $?$ & $\checkmark$ & $\checkmark$ & $?$ & $\checkmark$ \\
\hline Support of spin-offs creation & x & & $?$ & $\Rightarrow$ & $\Rightarrow$ & $?$ & $\checkmark$ \\
\hline Incubator services & x & & $\Rightarrow$ & $x$ & x & $?$ & $\Rightarrow$ \\
\hline $\begin{array}{l}\text { In the area of business cooperation and } \\
\text { promotion: }\end{array}$ & & & & & & & \\
\hline Joint purchasing & $\checkmark$ & $\Rightarrow$ & $?$ & $\checkmark$ & $\Rightarrow$ & $x$ & $\Rightarrow$ \\
\hline Shared production & $\checkmark$ & $\Rightarrow$ & $?$ & $\checkmark$ & $\checkmark$ & $x$ & $\Rightarrow$ \\
\hline Logistic management & $\Rightarrow$ & $\Rightarrow$ & $?$ & $\checkmark$ & $\Rightarrow$ & $x$ & $\checkmark$ \\
\hline Marketing, research of trends and markets & $\Rightarrow$ & $\checkmark$ & $\Rightarrow$ & $\checkmark$ & $\Rightarrow$ & $?$ & $\checkmark$ \\
\hline Joint participation in trade fairs & $\checkmark$ & $\checkmark$ & $\checkmark$ & $\checkmark$ & $\checkmark$ & $\Rightarrow$ & $\checkmark$ \\
\hline Catalogue of products of cluster members & $\Rightarrow$ & $\checkmark$ & $\checkmark$ & $\checkmark$ & $\checkmark$ & $x$ & $\checkmark$ \\
\hline Joint logo, trade name & $\checkmark$ & $\Rightarrow$ & $?$ & $\Rightarrow$ & $\checkmark$ & $\checkmark$ & $\checkmark$ \\
\hline Joint advertisement & $\checkmark$ & $\checkmark$ & $\checkmark$ & $\checkmark$ & $\checkmark$ & $\checkmark$ & $\checkmark$ \\
\hline Electronic marketplace & $x$ & $\Rightarrow$ & $?$ & $\Rightarrow$ & $x$ & $\checkmark$ & $\checkmark$ \\
\hline Support activities: & & & & & & & \\
\hline Help in management of projects & $\checkmark$ & $\checkmark$ & $\Rightarrow$ & $\checkmark$ & $\checkmark$ & $?$ & $\checkmark$ \\
\hline Benchmarking & $\checkmark$ & $\Rightarrow$ & $\Rightarrow$ & $\checkmark$ & $\Rightarrow$ & $\checkmark$ & $\checkmark$ \\
\hline Support service & $x$ & $\checkmark$ & $\checkmark$ & $x$ & $x$ & $\Rightarrow$ & $\checkmark$ \\
\hline In the governmental/political area: & & & & & & & \\
\hline Lobbying in favour of infrastructure & $\checkmark$ & $\checkmark$ & $\checkmark$ & $\checkmark$ & $\checkmark$ & $\checkmark$ & $\checkmark$ \\
\hline Lobbying in favour of legal regulations & $\checkmark$ & $\checkmark$ & $\checkmark$ & $\Rightarrow$ & $x$ & $\checkmark$ & $\checkmark$ \\
\hline Lobbying for subsidies & $\checkmark$ & $\checkmark$ & $\checkmark$ & $\checkmark$ & $x$ & $\checkmark$ & $\checkmark$ \\
\hline Other activities: & & & & & & & \\
\hline Joint investment in the infrastructure & $x$ & $\Rightarrow$ & $\checkmark$ & $\checkmark$ & $x$ & $?$ & $\checkmark$ \\
\hline Obtaining financial resources & $\checkmark$ & $\Rightarrow$ & $?$ & $\Rightarrow$ & $x$ & $x$ & $\checkmark$ \\
\hline
\end{tabular}

Tab. 1. Activities of clusters. Source: own research

$(\checkmark$ cluster currently offers; $\Rightarrow$ cluster is planning to offer; ? cluster doesn't offer, but is able to arrange; $\quad \boldsymbol{x}$ cluster neither offers, nor plans doing so)

\section{Key factors for the successful development of the cluster}

The widest dimension affecting the development of individual subjects is the framework of conditions on the microeconomic level; it concerns the external factors affecting the cluster development. Nationwide and regional strategies can contribute significantly to the formation and growth of clusters. However, clusters can emerge and develop even without the existence of the specific public policy for supporting clusters. Besides the conditions affecting the cluster from the outside, its growth is influenced by the other group of factors, which are internal factors. These factors 
Pavelkova, D.; Jircikova, E.; Knapkova, A.; Bialic-Davendra, M. \& Saha, N.: Emp...

proceed from the conditions of the function of individual clusters and can be influenced, for example, by the nature of the cluster, its structure, by the way it is managed, its goals etc.

Table 2 summarizes the opinions of managers of the above-mentioned clusters regarding the factors that were found to be of cardinal importance for a successful cluster development based on different studies.

Managers of different clusters agree on the high importance of professional cluster management, networking, mutual trust and communication of the cluster members. Additional activities, considered to be the key factors, are those focusing on the education of the personnel, cooperation with educational institutions and mutual research, possibly with a research organization. Important factors for a successful cluster development are deemed to be the access to sources of information, financial support during the formation and growth of a cluster as well as its own access to financial resources. There is no definite agreement regarding the importance of other factors.

\begin{tabular}{|c|c|c|c|c|c|c|c|}
\hline & $\mathrm{CZ}$ & SK & PL & $\mathrm{AU}$ & NO & USA & IND \\
\hline Professionalism of the cluster management & 5 & 5 & 4 & 5 & 5 & 5 & 5 \\
\hline Networking & 5 & 5 & 5 & 4 & 4 & 5 & 5 \\
\hline Mutual communication among companies & 5 & 5 & 5 & 3 & 5 & 5 & 5 \\
\hline Use of ICT/virtual media for communication & 1 & 4 & 3 & 2 & 5 & 3 & 5 \\
\hline Access of companies to information & 2 & 5 & 5 & 4 & 5 & 5 & 5 \\
\hline $\begin{array}{l}\text { Presence of a large dominant company in the } \\
\text { cluster }\end{array}$ & 2 & 3 & 4 & 2 & 2 & 4 & 1 \\
\hline $\begin{array}{l}\text { Presence of a multinational company in the } \\
\text { cluster }\end{array}$ & 1 & 5 & 3 & 2 & 1 & 3 & 1 \\
\hline Access to support services & 3 & 5 & 5 & 4 & 3 & 4 & 5 \\
\hline Competition rivalry among companies & 3 & 3 & 4 & 3 & 1 & 1 & 4 \\
\hline Developed infrastructure & 4 & 5 & 5 & 3 & 2 & 3 & 5 \\
\hline Innovative technology & 4 & 5 & 5 & 2 & 4 & 3 & 5 \\
\hline $\begin{array}{l}\text { Joint research/cooperation with a research } \\
\text { institution }\end{array}$ & 4 & 5 & 4 & 5 & 4 & 5 & 5 \\
\hline Education of human resources & 5 & 5 & 4 & 4 & 5 & 3 & 5 \\
\hline Cooperation with educational institutions & 5 & 5 & 4 & 3 & 4 & 5 & 5 \\
\hline Strong entrepreneurial spirit in companies & 2 & 5 & 4 & 4 & 4 & 5 & 5 \\
\hline $\begin{array}{l}\text { The cluster covers entire or most of the value } \\
\text { chain }\end{array}$ & 1 & 5 & 2 & 5 & 5 & 4 & 5 \\
\hline $\begin{array}{l}\text { Support by means of subsidies during mapping } \\
\text { and formation of the cluster }\end{array}$ & 4 & 5 & 4 & 5 & 4 & 5 & 5 \\
\hline
\end{tabular}




\begin{tabular}{|l|c|c|c|c|c|c|c|}
\hline $\begin{array}{l}\text { Support by means of subsidies during the } \\
\text { growth of the cluster }\end{array}$ & 5 & 5 & 4 & 3 & 4 & 5 & 4 \\
\hline Access to finances & 4 & 5 & 5 & 3 & 4 & 5 & 5 \\
\hline $\begin{array}{l}\text { Monitoring of productivity of companies in the } \\
\text { cluster }\end{array}$ & 4 & 5 & 5 & 2 & 4 & 3 & 5 \\
\hline Benchmarking & 4 & 5 & 5 & 5 & 2 & 3 & 5 \\
\hline $\begin{array}{l}\text { Lobbying in favour of infrastructure, } \\
\text { legislation, subsidies, etc. }\end{array}$ & 5 & 5 & 3 & 3 & 3 & 5 & 4 \\
\hline Mutual confidence of cluster members & 5 & 5 & 5 & 4 & 5 & 5 & 5 \\
\hline
\end{tabular}

Tab. 2. Key factors for the successful development of the cluster. Source: own research

(1 - not at all important, 5 - very important)

\section{Conclusion}

The development of clusters and cluster policies is one of the sources of attaining competitive advantages of companies and regions. There is a number of activities, which can be useful for the subjects in a cluster. This contribution analyzes a sample of seven clusters in the plastics industry from different countries (Western Europe - Norway, Austria; Central Europe - Czech Republic, Slovak Republic, Poland; Asia - India; North America - USA), including cluster policies that generate the framework for their growth. Although these clusters exist in different parts of the world and operate in different economic and cultural conditions, there are still many ideas and opinions shared by their managers.

\section{Acknowledgements}

This article was created with financial support of Operational Programme Research and Development for Innovations co-funded by the European Regional Development Fund (ERDF) and national budget of Czech Republic within the framework of the Centre of Polymer Systems project (reg.No: CZ.1.05/2.1.00/03.0111) and the Internal Grant Agency of Tomas Bata University in Zlín (reg. No. IGA/61/FaME/10/A) and the International Visegrad Fund (reg. No. 51000656).

\section{References}

Kačirková, M. (2008). Zhlukový potenciál v regiónoch nových členských krajín Európskej Únie, Ekonomickě Rozhl’ady, vol. 4, pp. 448-461, ISSN 0323-262X 